\title{
Establishment of An Advanced Chemically Defined Medium for Early Embryos Derived from In Vitro Matured and Fertilized Bovine Oocytes
}

\author{
Kenji MOMOZAWA ${ }^{\mathbf{1})}$ and Yoshinori FUKUDA ${ }^{\mathbf{1})}$ \\ 1) School of Veterinary Medicine, Kitasato University, Aomori 034-8628, Japan
}

\begin{abstract}
A chemically defined medium would be useful for analyzing promoters or inhibitors in in vitro culture (IVC) of bovine embryos. However, an IVC system for bovine embryos in a chemically defined medium has not been fully established. The present study was carried out to establish an advanced chemically defined medium for bovine embryos that supports a high rate of embryo development to the blastocyst stage. In the first experiment, we examined the effects of addition of Medium RD (RPMI1640 and Dulbecco's MEM, 1:1 v/v) to mKSOM/aa on developmental competence. The addition of $10 \% \mathrm{RD}$ to $\mathrm{mKSOM} /$ aa with BSA improved the rate of development to the blastocyst stage; however, $10 \%$ RD-mKSOM/aa with PVP, which is a chemically defined medium, caused a reduction in the percentage of hatching blastocysts. In the second experiment, embryos were cultured in the chemically defined medium of $10 \%$ RD-mKSOM/ aa containing 11.7, 23.4, 46.8, 70.2 or $96.8 \mu \mathrm{M}$ inositol. Inositol at the concentration of $70.2 \mu \mathrm{M}$ improved the rate of development to the hatching blastocyst stage. In the third experiment, the optimal RD concentration in the IVC medium was evaluated. Embryos were cultured in the chemically defined medium supplemented with 10, 20 or 30\% (v/v) RD. The rate of development to the blastocyst stage was highest with $20 \% \mathrm{RD}$. In the fourth experiment, the effects of Nacetylglucosamine (GlcNAc) as an IVC medium supplement on developmental competence were examined. The rate of development to the blastocyst stage with $1.0 \mathrm{mM}$ GlcNAc was significantly higher than that without GlcNAc, but the rate of development with 1.2 mM GlcNAc was not different from that without GlcNAc. We also evaluated the ability of blastocysts produced in RD-mKSOM/aa to develop to normal calves after being transferred into recipients. Ten of the 16 recipients became pregnant, with 9 delivering normal calves. These results indicate that $20 \% \mathrm{RD}-\mathrm{mKSOM} /$ aa containing $70.2 \mu \mathrm{M}$ myo-inositol and $1 \mathrm{mM}$ GlcNAc is useful as a chemically defined medium for IVC of bovine embryos.
\end{abstract}

Key words: Bovine embryos, Chemically defined medium, GlcNAc, Myo-inositol

(J. Reprod. Dev. 57 : 681-689, 2011)

$\boldsymbol{I}_{\mathrm{u}}$ vitro production (IVP) of bovine embryos by an in vitro maturation-fertilization culture system has been greatly improved. However, the rate of development of bovine oocytes to the blastocyst stage following maturation, fertilization and culture in vitro is limited to about $30-40 \%$ [1]. One possible reason for this is that embryo culture conditions, particularly the culture medium used for embryos, are suboptimal. Optimal conditions of a culture medium for embryos are 1) a high rate of embryo development to the blastocyst stage with repeatable results and 2) production of highquality blastocysts that have the competence to develop into competence to normal calves. In most studies on culture of mammalian embryos, the culture medium is supplemented with serum. A beneficial effect of serum on the development of bovine oocytes to the blastocyst stage has been reported [2-4]. However, serum contains many unknown factors, and the quality of serum can vary greatly depending on the source (animal and/or supplier) [5]. The use of serum also involves a risk of microbial contamination. Furthermore, serum is suspected of contributing to large offspring syndrome in sheep [6, 7] and calves [8]. Therefore, to support a high rate of

Received: March 25, 2011

Accepted: June 28, 2011

Published online in J-STAGE: July 30, 2011

(C)2011 by The Society for Reproduction and Development.

Correspondence: K Momozawa (e-mail: momozawa@vmas.kitasato-u. ac.jp) embryo development to the blastocyst stage with repeatable results and obtain high-quality blastocysts that have the competence to develop into normal calves, a culture system using a chemically defined medium must be established for IVP of bovine embryos. The use of a chemically defined medium would also provide consistent results and enable evaluation of factors that promote or prevent embryonic development. However, an IVC system for bovine embryos in a chemically defined medium has not been fully established. Various chemically defined media have been reported for bovine embryos, including SOF [9-11], CR1aa [12], BECM (bovine embryo culture medium) [2] and KSOM [13]. In mice, a simple medium named KSOM was used for successful culture of early embryos [14], but replacement of BSA in KSOM with PVA reduced the rate of blastocyst formation and severely inhibited hatching in vitro. The addition of amino acids to BSA-free KSOM was found to restore the rate of blastocyst formation and hatching $[15,16]$. In cattle, we have reported that modified KSOM/aa (mKSOM/aa) containing BSA and modified TCM199 (glucose-free) containing BSA were embryo culture media supporting development to the blastocyst stage [17]. However, in our preliminary experiment, $\mathrm{mKSOM} /$ aa with polyvinylpyrrolidone (PVP), which is a chemically defined medium, was found to markedly depress the rate of blastocyst formation.

On the other hand, protein-free Medium RD (RPMI1640 and Dulbecco's MEM, 1:1 v/v) was shown to be superior to TCM199 for culture of rabbit embryos [18]. Therefore, we hypothesized 
Table 1. Experiment design and treatment groups $\mathrm{s}^{\mathrm{a}}$

\begin{tabular}{|c|c|c|c|}
\hline \multirow{2}{*}{$\begin{array}{l}\text { Experi- } \\
\text { ment }\end{array}$} & \multicolumn{3}{|c|}{ Media } \\
\hline & Sperm capacitation & IVF & IVC \\
\hline 1 & $\begin{array}{l}\mathrm{FM}+0.1 \mu \mathrm{M} \mathrm{A} 23187^{\mathrm{b}}+1.5 \mathrm{U} / \mathrm{ml} \text { heparin } \\
+5 \mathrm{mM} \text { caffeine }\end{array}$ & $\mathrm{FM}+1.5 \mathrm{U} / \mathrm{ml}$ heparin & $\begin{array}{l}10 \% \mathrm{RD}-\mathrm{mKSOM} / \mathrm{aa}+10 \mathrm{mg} / \mathrm{ml} \mathrm{BSA} \text { or } \\
\mathrm{mKSOM} / \mathrm{aa}+10 \mathrm{mg} / \mathrm{ml} \mathrm{BSA} \text { or } \\
10 \% \mathrm{RD}-\mathrm{mKSOM} / \mathrm{aa}+1 \mathrm{mg} / \mathrm{ml} \mathrm{PVP} \\
+0.5 \mathrm{mM} \text { sodium citrate }\end{array}$ \\
\hline 2 & $\begin{array}{l}\mathrm{FM}+0.1 \mu \mathrm{M} \mathrm{A} 23187^{\mathrm{b}}+1.5 \mathrm{U} / \mathrm{ml} \text { heparin } \\
+5 \mathrm{mM} \text { caffeine }\end{array}$ & $\mathrm{FM}+1.5 \mathrm{U} / \mathrm{ml}$ heparin & $\begin{array}{l}10 \% \mathrm{RD}-\mathrm{mKSOM} / \mathrm{aa}+1 \mathrm{mg} / \mathrm{ml} \mathrm{PVP} \\
+0.5 \mathrm{mM} \text { sodium citrate } \\
+11.7,23.4,46.8,70.2 \text { or } 96.8 \mu \mathrm{M} \text { myo-inositol }\end{array}$ \\
\hline 3 & $\begin{array}{l}\text { BSA-free FM }+0.5 \mathrm{mg} / \mathrm{ml} \text { D-penicillamine } \\
+0.5 \mathrm{mM} \text { citrate }+0.25 \mathrm{mM} \text { methyl- } \beta \text {-cyclodextrin } \\
+1 \mathrm{mg} / \mathrm{ml} \mathrm{PVP}+5 \mathrm{mM} \text { caffeine }\end{array}$ & $\begin{array}{l}\text { BSA-free FM } \\
+1 \mathrm{mg} / \mathrm{ml} \mathrm{PVP}\end{array}$ & $\begin{array}{l}\text { 10, } 20 \text { or } 30 \% \mathrm{RD}-\mathrm{mKSOM} / \mathrm{aa}+1 \mathrm{mg} / \mathrm{ml} \mathrm{PVP} \\
+0.5 \mathrm{mM} \text { sodium citrate }+70.2 \mu \mathrm{M} \text { myo-inositol }\end{array}$ \\
\hline 4 & $\begin{array}{l}\text { BSA-free FM }+0.5 \mathrm{mg} / \mathrm{ml} \mathrm{D-penicillamine} \\
+0.5 \mathrm{mM} \text { citrate }+0.25 \mathrm{mM} \text { methyl- } \beta \text {-cyclodextrin } \\
+1 \mathrm{mg} / \mathrm{ml} \mathrm{PVP}+5 \mathrm{mM} \text { caffeine }\end{array}$ & $\begin{array}{l}\text { BSA-free FM } \\
+1 \mathrm{mg} / \mathrm{ml} \mathrm{PVP}\end{array}$ & $\begin{array}{l}20 \% \mathrm{RD}-\mathrm{mKSOM} / \mathrm{aa}+1 \mathrm{mg} / \mathrm{ml} \mathrm{PVP} \\
+0.5 \mathrm{mM} \text { sodium citrate }+70.2 \mu \mathrm{M} \text { myo-inositol } \\
+0,0.6,1.0 \text { or } 1.2 \mathrm{mM} \mathrm{N} \text {-acetylglucosamine }\end{array}$ \\
\hline
\end{tabular}

${ }^{\mathrm{a}}$ IVM was described in Materials and Methods. ${ }^{\mathrm{b}}$ Calcium ionophore A23187.

that Medium RD could be superior to TCM199 for culture of bovine embryos. However, the glucose concentration in Medium RD $(8.3 \mathrm{mM})$ is too high for bovine embryos. Accordingly, we considered using RD as a supplement for mKSOM/aa (10\%RD-mKSOM/ aa, RD and $\mathrm{mKSOM} / \mathrm{aa}, 1: 9 \mathrm{v} / \mathrm{v})$. Carney and Foote suggested that a high concentration $(117 \mu \mathrm{M})$ of inositol in RD promotes the development of rabbit embryos [18]. The original concentration of inositol in $10 \% \mathrm{RD}-\mathrm{mKSOM} / \mathrm{aa}$ was $11.7 \mu \mathrm{M}$. However, the optimal concentration of inositol in 10\% RD-mKSOM/aa for bovine embryos has not been determined.

Furthermore, N-acetylglucosamine (GlcNAc) exists widely as a component of glycoprotein and glycosaminoglycan in both animals and plants cells. Nancarrow and Hill [19] reported that an oviductspecific glycoprotein was secreted mainly from day -1 to day 3 of the ovarian cycle and that this ovine estrus-associated glycoprotein enhanced the proportion of sheep oocytes that cleaved in vitro. Additionally, a serum-free medium of chinese hamster ovary cells containing $1 \mathrm{mM}$ GlcNAc markedly enhanced cell proliferation (Nakano, personal communication). Therefore, we considered the effect on IVC of supplementation of a chemically defined medium for bovine embryos with GlcNAc.

The objective of this study was to establish an advanced chemically defined medium for bovine embryos that supports a high rate of embryo development to the blastocyst stage. In the first experiment, we examined the effects of addition of Medium RD to mK$\mathrm{SOM} / \mathrm{aa}$ on developmental competence. In the second experiment, embryos were cultured in the chemically defined medium of $10 \%$ RD-mKSOM/aa containing various concentrations of inositol. In the third experiment, we evaluated the optimal RD concentration in the IVC medium. In the fourth experiment, we examined the effects of GlcNAc as an IVC medium supplement on developmental competence. Moreover, we evaluated the ability of blastocysts pro- duced in RD-mKSOM/aa to develop to normal calves after being transferred into recipients.

\section{Materials and Methods}

\section{In vitro maturation (IVM) of oocytes}

Cattle ovaries (mostly from crossbred cows) obtained at a local abattoir were wrapped in paper towels soaked in $0.9 \%$ saline and transported to the laboratory at about $30 \mathrm{C}$. Cumulus-oocyte complexes (COCs) were aspirated from 2-6-mm follicles of ovaries into a 5-ml disposable syringe with a 21-gauge needle and were placed in plastic Petri dishes. Fully grown oocytes with an unexpanded cumulus (more than 5 layers) and nonpolar ooplasm filling the perivitelline space were washed several times with maturation medium. COCs were divided into two groups by the appearance of their ooplasm, homogeneous (finely, evenly granulated) or heterogeneous (unevenly granulated to various degrees) [20], and cultured for $24 \mathrm{~h}$ in $50-\mu \mathrm{l}$ droplets of maturation medium under mineral oil (Bristol-Myers Squibb, Princeton, NJ, USA) in culture dishes (35 $\times 10 \mathrm{~mm}$, Nunc, Roskilde, Denmark) in a $\mathrm{CO}_{2}$ incubator $\left(5 \% \mathrm{CO}_{2}, 95 \%\right.$ humidified air, $\left.39 \mathrm{C}\right)$. Each droplet contained about 10 COCs. The maturation medium was $10 \mathrm{mM}$ HEPES-buffered TCM-199 (Nissui Pharmaceutical, Tokyo, Japan) supplemented with $0.3 \mathrm{mM}$ sodium pyruvate, $0.5 \mathrm{IU} / \mathrm{ml} \mathrm{hFSH}$ (containing 2.31 IU/ml LH, Biogenesis, England, U.K.), $1 \mu \mathrm{g} / \mathrm{ml}$ estradiol-17 $\beta$ (Sigma-Aldrich, St. Louis, MO, USA), $3 \mathrm{mg} / \mathrm{ml}$ polyvinylpyrrolidone (PVP, $M_{\text {r. }}$ 40,000, Sigma), $65 \mu \mathrm{g} / \mathrm{ml}$ dibekacin sulfate (Meiji-Seika, Tokyo, Japan) and 1.5\% 2nd fraction of ultracentrifuged bovine follicular fluid (bFF). The 2 nd fraction of bFF was prepared by ultracentrifugation of $\mathrm{bFF}$ at $220,000 \times g$ for $48 \mathrm{~h}$ at $4 \mathrm{C}$ [17]. 
Sperm preparation and in vitro fertilization (IVF)

The basic medium for sperm washing, capacitation and insemination was modified BO medium [21], hereafter referred to as fertilization medium (FM), which consisted of $113.45 \mathrm{mM} \mathrm{NaCl}$, $4.02 \mathrm{mM} \mathrm{KCl}, 2.25 \mathrm{~m} \mathrm{M} \mathrm{CaCl}_{2} \cdot 2 \mathrm{H}_{2} \mathrm{O}, 0.83 \mathrm{mM} \mathrm{NaH}_{2} \mathrm{PO}_{4} \cdot 2 \mathrm{H}_{2} \mathrm{O}$, $0.52 \mathrm{mM} \mathrm{MgCl} 2 \cdot 6 \mathrm{H}_{2} \mathrm{O}, 25 \mathrm{mM} \mathrm{NaHCO}, 13.90 \mathrm{mM}$ glucose, $12.5 \mathrm{mM}$ HEPES (pH 7.4), $65 \mu \mathrm{g} / \mathrm{ml}$ dibekacin sulfate, $10 \mathrm{mg} / \mathrm{ml}$ BSA (fraction V, Wako Pure Chemical Industries, Osaka, Japan) and $2 \times 10^{-4} \%(\mathrm{w} / \mathrm{v})$ phenol red [20]. The methods used for sperm washing were the same in all experiments, but the methods used for sperm capacitation and insemination were different in the experiments (Table 1). One straw $(0.5 \mathrm{ml} / \mathrm{straw})$ of frozen semen of Japanese Black cattle was thawed in a water bath at $39 \mathrm{C}$ for 20 $\mathrm{sec}$, suspended in $5 \mathrm{ml}$ of BSA-free FM supplemented with $10 \mathrm{mM}$ caffeine (sodium benzoate, Sigma-Aldrich), and washed twice by centrifugation at $700 \times g$ for $5 \mathrm{~min}$. In experiments 1 and 2, the method used for sperm capacitation was the same as that described previously [22]. Spermatozoa resuspended in $1 \mathrm{ml}$ of BSA-free FM supplemented with $10 \mathrm{mM}$ caffeine were treated with $0.1 \mu \mathrm{M}$ Ca ionophore A23187 (Calbiochem-Behring, La Jolla, CA, USA) for $60 \mathrm{sec}$. After treatment, the sperm suspension was immediately diluted 1:1 with FM containing $20 \mathrm{mg} / \mathrm{ml}$ BSA supplemented with 3 units $/ \mathrm{ml}$ heparin (heparin sodium salt, Wako). The spermatozoa were preincubated for $3 \mathrm{~h}$ in a $\mathrm{CO}_{2}$ incubator $\left(5 \% \mathrm{CO}_{2}\right.$, $95 \%$ humidified air, $39 \mathrm{C}$ ). The sperm concentration at preincubation was about $1 \times 10^{7} \mathrm{sperm} / \mathrm{ml}$. After the 3 -h preincubation, a small amount of sperm suspension was introduced into each $40-\mu \mathrm{l}$ droplet of FM supplemented with 1.5 units $/ \mathrm{ml}$ heparin to obtain a final concentration of $120 \mathrm{sperm} / \mu \mathrm{l}$. Subsequently, COCs were introduced into droplets of sperm suspension (about 10 oocytes/ drop). In experiments 3 and 4, the method used for sperm capacitation was the same as that described previously [23] with some modifications. The washed spermatozoa were resuspended in $0.5 \mathrm{ml}$ of BSA-free FM supplemented with $10 \mathrm{mM}$ caffeine. The sperm suspension was diluted 1:1 with BSA-free FM supplemented with $1.0 \mathrm{mg} / \mathrm{ml}$ penicillamine (Sigma-Aldrich), $0.5 \mathrm{mM}$ methyl$\beta$-cyclodextrin (Sigma-Aldrich), $1.0 \mathrm{mM}$ citrate (sodium citratetrisodium salt, Kanto Chemical, Tokyo, Japan) and $1 \mathrm{mg} / \mathrm{ml}$ PVP. The spermatozoa were preincubated for $4 \mathrm{~h}$ in a $\mathrm{CO}_{2}$ incubator $(5 \%$ $\mathrm{CO}_{2}, 95 \%$ humidified air, $39 \mathrm{C}$ ). The sperm concentration at preincubation was about $2 \times 10^{7} \mathrm{sperm} / \mathrm{ml}$. After the 4 -h preincubation, $5 \mu 1$ of sperm suspension was introduced into each $40-\mu 1$ droplet of BSA-free FM with $1.0 \mathrm{mg} / \mathrm{ml}$ PVP. Eventually, the sperm concentration at insemination was about $1,000 \mathrm{sperm} / \mu \mathrm{l}$. At $30 \mathrm{~min}$ after introduction of sperm, COCs at $24 \mathrm{~h}$ after IVM were introduced into the droplets of sperm suspension (about 10 oocytes/drop). In all experiments, spermatozoa and oocytes were coincubated for $6 \mathrm{~h}$ in a $\mathrm{CO}_{2}$ incubator $\left(5 \% \mathrm{CO}_{2}, 95 \%\right.$ humidified air, $\left.39 \mathrm{C}\right)$.

\section{In vitro embryo culture (IVC)}

At $6 \mathrm{~h}$ after insemination, oocytes were freed from cumulus cells by repeated pipetting. Subsequently, presumptive zygotes were cultured for $240 \mathrm{~h}$ in $50-\mu \mathrm{l}$ of culture medium covered with mineral oil under a gas-phase of $5 \% \mathrm{CO}_{2}, 5 \% \mathrm{O}_{2}$ and $90 \% \mathrm{~N}_{2}$ with high humidity at $39 \mathrm{C}$. Each droplet contained approximately 10 presumptive zygotes. At $96 \mathrm{~h}$ after insemination, embryos at the 8-cell stage or a more advanced stage were transferred to a fresh culture medium supplemented with $10 \mu \mathrm{M} \beta$-mercaptoethanol ( $\beta$ ME; Sigma-Aldrich). At 120-144 h after insemination, embryos at the morula stage or a more advanced stage were transferred to a fresh culture medium supplemented with $50 \mu \mathrm{M} \beta$-ME. Oocytes that did not progress to the next cleavage stage were removed from drops containing developing embryos. Cleavage and development to the 8-cell or more advanced stage, to the morula stage and to the blastocyst stage were observed at 48, 96, 120-144 and 144-216 h after insemination, respectively, under an inverted microscope.

\section{Embryo freezing}

Excellent or good blastocysts at Days 6-9 (Day $0=$ day of insemination) were placed into a freezing medium at room temperature $(20 \mathrm{C})$. The basic freezing medium was modified PB1 medium [24]. This medium, designated as $\mathrm{mPB1}$, contained $1 \mathrm{mg} / \mathrm{ml}$ PVP instead of BSA. The freezing medium consisted of mPB1 supplemented with $14.8 \mathrm{mM}$ L-proline [25], $0.2 \mathrm{M}$ trehalose, 7\% (v/v) ethylene glycol and $0.5 \%(\mathrm{v} / \mathrm{v})$ glycerol. Embryos were loaded into $0.25-\mathrm{ml}$ straws (IMV, France) and placed at $-7 \mathrm{C}$ in a methanol bath in a programmable freezer. Seeding was induced immediately. Samples were held for about $1 \mathrm{~min}$ at $-7 \mathrm{C}$ after seeding, cooled at $0.5 \mathrm{C} / \mathrm{min}$ to $-25 \mathrm{C}$, and then placed in liquid nitrogen gas, plunged and stored in liquid nitrogen at $-196 \mathrm{C}$ for $30-50$ days.

\section{Experimental design}

The experimental design is presented in Table 1.

Experiment 1: Effects of addition of Medium RD to $\mathrm{mKSOM} / \mathrm{aa}$

The embryo culture medium used for a control was modified $\mathrm{KSOM} / \mathrm{aa}$ [15], hereafter referred to as $\mathrm{mKSOM} / \mathrm{aa}$, which consisted of $98.6 \mathrm{mM} \mathrm{NaCl} ; 2.5 \mathrm{mM} \mathrm{KCl} ; 1.71 \mathrm{mM} \mathrm{CaCl} 2 ; 0.35 \mathrm{mM}$ $\mathrm{KH}_{2} \mathrm{PO}_{4} ; 0.2 \mathrm{mM} \mathrm{MgSO}$; $0.3 \mathrm{mM}$ sodium pyruvate; $3.0 \mathrm{mM}$ sodium lactate; $25 \mathrm{mM} \mathrm{NaHCO}$; $0.68 \mathrm{mM} \mathrm{L-glutamine;} \mathrm{premix-}$ ture solutions of 12 essential amino acids for basal medium Eagle (Sigma-Aldrich) and 7 nonessential amino acids for minimum essential medium (Sigma-Aldrich; final concentrations of L-leucine, L-methionine, L-tryptophan and glycine being modified to 0.4 , $0.1,0.05$ and $3 \mathrm{mM}$, respectively); $10 \mathrm{mM}$ HEPES; $5 \mu \mathrm{g} / \mathrm{ml}$ insulin, $5 \mu \mathrm{g} / \mathrm{ml}$ transferrin and $5 \mathrm{ng} / \mathrm{ml}$ sodium selenite (ITS media supplement, Sigma-Aldrich); $10 \mu \mathrm{M}$ EDTA; and $65 \mu \mathrm{g} / \mathrm{ml}$ dibekacin sulfate [17]. The embryo culture medium used for treatment was $\mathrm{mKSOM}$ /aa supplemented with 10\% (v/v) RD (RPMI1640 and Dulbecco's MEM, 1:1 v/v) [18], hereafter referred to as 10\% RD$\mathrm{mKSOM} / \mathrm{aa}$, which contained an increased concentration of glucose $(1 \mathrm{mM})$. Presumptive zygotes were cultured in $10 \% \mathrm{RD}-\mathrm{mK}$ $\mathrm{SOM} / \mathrm{aa}$ with $10 \mathrm{mg} / \mathrm{ml} \mathrm{BSA}, 10 \% \mathrm{RD}-\mathrm{mKSOM} / \mathrm{aa}$ with $1 \mathrm{mg} / \mathrm{ml}$ PVP and $0.5 \mathrm{mM}$ sodium citrate or $\mathrm{mKSOM} /$ aa with $1 \mathrm{mM}$ glucose and $10 \mathrm{mg} / \mathrm{ml} \mathrm{BSA}$. In all experiments, the glucose concentration in the culture medium was adjusted to $1 \mathrm{mM}$. The RPMI1640 used in experiment 1 was purchased from Life Technologies Corporation (Cat. no. 11875, Life Technologies, Grand Island, NY, USA), and the Dulbecco's MEM (low glucose) used in experiment 1 was purchased from Sigma-Aldrich (Cat. No. D6046). Experiments were performed at least three times. 
Table 2. Effect of addition of Medium RD to $\mathrm{mKSOM} / \mathrm{aa}$ on development to the blastocyst stage of bovine IVM-IVF oocytes

\begin{tabular}{|c|c|c|c|c|c|c|c|c|}
\hline \multirow{2}{*}{$\begin{array}{l}\text { Type of } \\
\text { oocytes }\end{array}$} & \multirow{2}{*}{$\begin{array}{c}\text { Culture } \\
\text { media }\end{array}$} & \multirow{2}{*}{$\begin{array}{c}\text { Replacement } \\
\text { with a chemically } \\
\text { defined medium }\end{array}$} & \multirow{2}{*}{$\begin{array}{c}\text { No. of } \\
\text { oocytes } \\
\text { examined }\end{array}$} & \multicolumn{4}{|c|}{ No. $(\%)$ of oocytes developed to } & \multirow{2}{*}{$\begin{array}{l}\text { Hatching } \\
\text { rate }(\%) \text { of } \\
\text { blastocysts }\end{array}$} \\
\hline & & & & $\geq 2$ cells & $\geq 8$ cells & Morula & Blastocyst & \\
\hline \multirow[t]{3}{*}{ Hetero $^{1}$} & $\mathrm{mKSOM} / \mathrm{aa}$ & $\mathrm{No}^{\mathrm{a})}$ & 115 & 94 (81.7) & $78(67.8)^{\mathrm{d}}$ & $67(58.3)^{\mathrm{d}}$ & $62(53.9)^{\mathrm{d}}$ & $71.0^{\mathrm{f}}$ \\
\hline & $10 \% \mathrm{RD}-\mathrm{mKSOM} / \mathrm{aa}$ & $\mathrm{No}^{\mathrm{b})}$ & 114 & $103(90.4)$ & $94(82.5)^{\mathrm{e}}$ & $80(70.2)^{\mathrm{e}}$ & $73(64.0)^{\mathrm{e}}$ & $82.2^{\mathrm{f}}$ \\
\hline & $10 \% \mathrm{RD}-\mathrm{mKSOM} / \mathrm{aa}$ & Yes $^{\mathrm{c})}$ & 111 & $91(82.0)$ & $81(73.0)^{\mathrm{d}}$ & $67(60.4)^{\mathrm{d}}$ & $56(50.5)^{\mathrm{d}}$ & $16.1^{\mathrm{g}}$ \\
\hline \multirow[t]{3}{*}{ Homo $^{2}$} & $\mathrm{mKSOM} / \mathrm{aa}$ & $\mathrm{No}^{\mathrm{a})}$ & 69 & $55(79.7)$ & $39(56.5)$ & $30(43.5)$ & $28(40.6)$ & $67.9^{\mathrm{f}}$ \\
\hline & $10 \% \mathrm{RD}-\mathrm{mKSOM} / \mathrm{aa}$ & $\mathrm{No}^{\mathrm{b})}$ & 94 & $69(73.4)$ & $50(53.2)$ & $36(38.3)$ & $33(35.1)$ & $93.9^{\mathrm{g}}$ \\
\hline & $10 \% \mathrm{RD}-\mathrm{mKSOM} / \mathrm{aa}$ & Yes $^{\mathrm{c})}$ & 30 & $24(80.0)$ & $21(70.0)$ & $16(53.3)$ & $10(33.3)$ & $20.0^{\mathrm{h}}$ \\
\hline
\end{tabular}

${ }^{1}$ Heterogeneous ooplasm. ${ }^{2}$ Homogeneous ooplasm. a) The culture medium was mKSOM/aa with $10 \mathrm{mg} / \mathrm{ml} \mathrm{BSA.} \mathrm{b)} \mathrm{The} \mathrm{culture} \mathrm{medium} \mathrm{was} 10 \%$ RD-mKSOM/aa with $10 \mathrm{mg} / \mathrm{ml}$ BSA. ${ }^{\text {c) }}$ The culture medium was $10 \% \mathrm{RD}-\mathrm{mKSOM} / \mathrm{aa}$ with $1 \mathrm{mg} / \mathrm{ml} \mathrm{PVP}$ and $0.5 \mathrm{mM}$ citrate. ${ }^{\mathrm{d}-\mathrm{h}}$ Values in the same column with different superscripts are significantly different for each type of oocyte ( $\mathrm{P}<0.05$ for $\mathrm{d}$ and $\mathrm{e}$, and $\mathrm{P}<0.01$ for $\mathrm{f}, \mathrm{g}$ and $\mathrm{h}$ ).

Experiment 2: Effects of various concentrarions of myo-inositol in $10 \%$ RD-mKSOM/aa

Presumptive zygotes were cultured in $10 \% \mathrm{RD}-\mathrm{mKSOM} / \mathrm{aa}$ with $1 \mathrm{mg} / \mathrm{ml}$ PVP, $0.5 \mathrm{mM}$ citrate and myo-inositol at various concentrations. Inositol was used at concentrations of 11.7, 23.4, 46.8, 70.2 and $93.6 \mu \mathrm{M}$. The original concentration of myo-inositol in $10 \%$ RD-mKSOM/aa was $11.7 \mu \mathrm{M}$. The RPMI1640 used in experiment 2 was purchased from Life Technologies (Cat. no. 11875), and the Dulbecco's MEM (low glucose) used in experiment 2 was purchased from Sigma-Aldrich (Cat. No. D6046). Experiments were performed at least twice.

\section{Experiment 3: Optimal RD concentrations in IVC medium}

Presumptive zygotes were cultured in $\mathrm{mKSOM} /$ aa supplemented with 10,20 or $30 \%$ (v/v) RD, $1 \mathrm{mg} / \mathrm{ml}$ PVP, $0.5 \mathrm{mM}$ citrate and $70.2 \mu \mathrm{M}$ myo-inositol. The RPMI1640 (without glucose and phenol red) and Dulbecco's MEM (without glucose, sodium pyruvate and phenol red) in experiment 3 were prepared as a customized medium by Kojin-bio (Sakado, Japan). In this experiment, the concentrations of inorganic salts, sodium pyruvate, sodium lactate, $\mathrm{NaHCO}_{3}$, L-glutamine, glycine, HEPES, EDTA, ITS and dibekacin sulfate contained in the culture medium were the same as those in $\mathrm{mKSOM} / \mathrm{aa}$. Experiments were performed at least four times.

\section{Experiment 4: Effects of supplementation of $\mathrm{N}$-acetylglucos- amine (GlcNAc)}

Presumptive zygotes were cultured in $20 \%$ RD-mKSOM/aa with $0,0.6,1$ or $1.2 \mathrm{mM} \mathrm{GlcNAc}, 1 \mathrm{mg} / \mathrm{ml}$ PVP, $0.5 \mathrm{mM}$ citrate and $70.2 \mu \mathrm{M}$ myo-inositol. The RPMI1640 (without glucose and phenol red) used in experiment 4 was prepared as a customized medium by Kojin-bio, and the Dulbecco's MEM (low glucose) used in experiment 4 was purchased from Sigma-Aldrich (Cat. No. D6046). Experiments were performed at least four times.

\section{Experiment 5: Cryopreservation ability of blastocysts produced} with $10 \%$ RD-mKSOM/aa

In this experiment, blastocysts developed in $10 \% \mathrm{RD}-\mathrm{mKSOM} /$ aa with $1 \mathrm{mg} / \mathrm{ml}$ PVP, $0.5 \mathrm{mM}$ citrate and $70.2 \mu \mathrm{M}$ myo-inositol were used for cryopreservation. In addition, frozen-thawed blastocysts were cultured in $10 \%$ RD-mKSOM/aa containing $10 \mathrm{mg} / \mathrm{ml}$ BSA and $100 \mu \mathrm{M} \beta-\mathrm{ME}$, which is not a chemically defined medi- um, in order to observe hatching. For thawing, each straw containing frozen embryos was held in air for $12 \mathrm{sec}$ and then in $35 \mathrm{C}$ water for $8 \mathrm{sec}$. The embryo was removed from the straw and placed in a drop in PB1 supplemented with $20 \%$ fetal bovine serum for $10 \mathrm{~min}$ at $39 \mathrm{C}$. After thawing, the embryos were cultured for $168 \mathrm{~h}$ under a gas phase of $5 \% \mathrm{CO}_{2}, 5 \% \mathrm{O}_{2}$ and $90 \% \mathrm{~N}_{2}$ with high humidity at 39 C. Survival of embryos (i.e., embryos that reexpanded and continued development) up to $48 \mathrm{~h}$ after thawing and hatching up to $168 \mathrm{~h}$ after thawing were assessed.

Experiment 6: Ability of blastocysts produced with $\mathrm{mKSOM} / \mathrm{aa}$ supplemented with $10 \%$ or $20 \%$ RD to develop into live calves

In this experiment, 7 fresh blastocysts and 9 frozen-thawed blastocysts were used for embryo transfer. Fresh bastocysts were produced with $10 \%$ RD-mKSOM/aa containing $1 \mathrm{mg} / \mathrm{ml} \mathrm{PVP,}$ $0.5 \mathrm{mM}$ citrate and $70.2 \mu \mathrm{M}$ myo-inositol. Frozen-thawed blastocysts were produced with $20 \% \mathrm{RD}-\mathrm{mKSOM} /$ aa containing $1 \mathrm{mg} /$ $\mathrm{ml}$ PVP, $0.5 \mathrm{mM}$ citrate, $70.2 \mu \mathrm{M}$ myo-inositol and 0 or $1 \mathrm{mg} /$ $\mathrm{ml} \mathrm{mM} \mathrm{GlcNAc.} \mathrm{Excellent} \mathrm{or} \mathrm{good} \mathrm{blastocysts} \mathrm{at} \mathrm{Days} \mathrm{6-7} \mathrm{(Day}$ $=$ day of insemination) were subjected to cryopreservation by conventional freezing. Frozen-thawed blastocysts were cultured overnight by the same method as that used in experiment 5 . Excellent blastocysts were selected for embryo transfer. The recipient cows were synchronized by treatment with a progesterone device (CIDR, InterAg, Hamilton, New Zealand) for 14 days. A single blastocyst was transferred nonsurgically into the uterine horn ipsilateral to the corpus luteum of each recipient on Day 6 (1 recipient), 8 (14 recipients) or 9 ( 1 recipient) of the estrous cycle (Day $0=$ day of estrus).

\section{Statistical analysis}

Percentage data were subjected to an arcsine transformation and analyzed by one-way ANOVA. Treatment differences were determined using Tukey's multiple comparison test.

\section{Results}

Experiment 1: Effects of addition of Medium RD to $\mathrm{mKSOM} / \mathrm{a} a$

The results of experiment 1 are presented in Table 2. In the oocytes with heterogeneous ooplasm, the rates of development to the 8 -cell or more advanced stage, morula stage and blastocyst stage 
Table 3. Effect of various concentrations of myo-inositol in 10\% RD-mKSOM/aa on development to the blastocyst stage of bovine IVM-IVF oocytes

\begin{tabular}{|c|c|c|c|c|c|c|c|}
\hline \multirow{2}{*}{$\begin{array}{l}\text { Type of } \\
\text { oocytes }\end{array}$} & \multirow{2}{*}{$\begin{array}{l}\text { Concentration of } \\
\text { myo-insitol }(\mu \mathrm{M})\end{array}$} & \multirow{2}{*}{$\begin{array}{c}\text { No. of } \\
\text { oocytes } \\
\text { examined }\end{array}$} & \multicolumn{4}{|c|}{ No. (\%) of oocytes developed to } & \multirow{2}{*}{$\begin{array}{l}\text { Hatching } \\
\text { rate }(\%) \text { of } \\
\text { blastocyst }\end{array}$} \\
\hline & & & $\geq 2$ cells & $\geq 8$ cells & Morula & Blastocyst & \\
\hline \multirow[t]{5}{*}{ Hetero } & $11.7^{\mathrm{a}}$ & 111 & $91(82.0)^{\mathrm{bc}}$ & $81(73.0)^{b}$ & 67 (60.4) & $56(50.5)$ & $16.1^{\mathrm{b}}$ \\
\hline & 23.4 & 120 & $103(85.8)^{\mathrm{b}}$ & $95(79.2)^{b}$ & $75(62.5)$ & $66(55.0)$ & $36.4^{\mathrm{c}}$ \\
\hline & 46.8 & 108 & $91(84.3)^{b}$ & $84(77.8)^{b}$ & $69(63.9)$ & $54(50.0)$ & $42.6^{\mathrm{cd}}$ \\
\hline & 70.2 & 116 & $91(78.4)^{\mathrm{bc}}$ & $80(69.0)^{\mathrm{bc}}$ & $71(61.2)$ & $66(56.9)$ & $45.5^{\mathrm{cd}}$ \\
\hline & 93.6 & 74 & $53(71.6)^{\mathrm{c}}$ & $43(53.1)^{\mathrm{c}}$ & $40(54.1)$ & $36(48.6)$ & $33.3^{\mathrm{bc}}$ \\
\hline \multirow[t]{5}{*}{ Homo } & $11.7^{\mathrm{a}}$ & 30 & $24(80.0)$ & $21(70.0)$ & $16(53.3)$ & $10(33.3)$ & $20.0^{\mathrm{bc}}$ \\
\hline & 23.4 & 48 & $35(72.9)$ & $27(56.3)$ & $17(35.4)$ & $14(29.2)$ & $14.3^{\mathrm{bc}}$ \\
\hline & 46.8 & 88 & $63(71.6)$ & $50(56.8)$ & $41(46.6)$ & $30(34.1)$ & $10.0^{\mathrm{b}}$ \\
\hline & 70.2 & 38 & $27(71.1)$ & $23(60.5)$ & $18(47.4)$ & $14(36.8)$ & $42.9^{c}$ \\
\hline & 93.6 & 20 & $13(65.0)$ & $7(35.0)$ & $6(30.0)$ & $4(20.0)$ & $0.0^{\mathrm{bc}}$ \\
\hline
\end{tabular}

${ }^{a}$ The original concentration in $10 \%$ RD-mKSOM/aa. ${ }^{b, c, d}$ Values in the same column with different superscripts are significantly different for each type of oocyte $(\mathrm{P}<0.05$ for $\mathrm{b} v s$. $\mathrm{c}$, and $\mathrm{P}<0.01$ for $\mathrm{b} v s$. $\mathrm{d})$.

Table 4. Effect of various concentations of RD in in vitro culture medium on development to the blastocyst stage of bovine IVM-IVF oocytes

\begin{tabular}{lcccccc}
\hline \multirow{2}{*}{$\begin{array}{c}\text { Type of } \\
\text { oocytes }\end{array}$} & $\begin{array}{c}\text { Concentration } \\
\text { of }\end{array}$ & \multirow{2}{*}{$\begin{array}{c}\text { No. of } \\
\text { oocytes } \\
\text { examined }\end{array}$} & & \multicolumn{3}{c}{ No. (\%) of oocytes developed to } \\
\cline { 4 - 6 } & RD (\%) & 102 & $81(79.4)$ & $68(66.7)$ & $59(57.8)$ & $44(43.1)$ \\
\hline Hetero & 10 & 97 & $88(90.7)$ & $76(78.4)$ & $62(63.9)$ & $47(48.5)$ \\
& 20 & 94 & $78(83.0)$ & $65(69.1)$ & $48(51.1)$ & $34(36.2)$ \\
\hline Homo & 30 & 50 & $40(80.0)$ & $33(66.0)$ & $26(52.0)^{\mathrm{a}}$ & $18(36.0)^{\mathrm{ab}}$ \\
& 10 & 57 & $46(80.7)$ & $39(68.4)$ & $37(64.9)^{\mathrm{a}}$ & $25(43.9)^{\mathrm{a}}$ \\
& 20 & 57 & $42(73.7)$ & $33(57.9)$ & $16(28.1)^{\mathrm{b}}$ & $12(21.1)^{\mathrm{b}}$ \\
\hline
\end{tabular}

${ }^{a, b}$ Values in the same column with different superscripts are significantly different for each type of oocyte $(\mathrm{P}<0.05)$.

with $10 \%$ RD-mKSOM/aa containing BSA were significantly higher than those with $\mathrm{mKSOM}$ /aa containing BSA. On the other hand, the rates of development to the 8-cell or more advanced stage, morula stage, blastocyst stage and hatching blastocyst stage with $10 \% \mathrm{RD}-\mathrm{mKSOM}$ /aa containing PVP, which is a chemically defined medium, were lower than those with $10 \%$ RD-mKSOM/ aa containing BSA. There were no differences in the rate of development to the blastocyst stage between 10\% RD-mKSOM/aa containing PVP and $\mathrm{mKSOM} / \mathrm{aa}$ containing BSA. However, 10\% RD-mKSOM/aa containing PVP caused a reduction in the percentage of hatching blatocysts compared with that obtained with $\mathrm{mKSOM} / \mathrm{aa}$ containing BSA. On the other hand, in the oocytes with homogeneous ooplasm, the rates of cleavage and development to the 8-cell or more advanced stage, morula stage and blastocyst stage were not different among the groups. However, the rate of development to the hatching blastocyst stage with $10 \% \mathrm{RD}-\mathrm{mKSOM} /$ aa containing PVP was significantly lower than the rates obtained with $\mathrm{mKSOM} / \mathrm{aa}$ containing BSA and 10\% RD-mKSOM/aa containing BSA.
Experiment 2: Effects of various concentrarions of myo-inositol in a chemically defined medium of $10 \%$ RD-mKSOM/aa

The results of experiment 2 are presented in Table 3. In the oocytes with heterogeneous ooplasm, the rates of development to the blastocyst stage were not different among the groups. While not significant, the rate of development to the blastocyst stage with inositol at the concentration of $70.2 \mu \mathrm{M}$ was the highest among the groups. The percentage of hatching blastocysts was increased dose-dependently by inositol at concentrations from 23.4 to 70.2 $\mu \mathrm{M}$. The percentages of hatching blastocysts with 23.4, 46.8 and $70.2 \mu \mathrm{M}$ inositol were significantly higher than that with $11.7 \mu \mathrm{M}$ inositol. On the other hand, in the oocytes with homogeneous ooplasm, the rates of development to the blastocyst stage were not different among the groups. However, the percentage of hatching blastocysts with $70.2 \mu \mathrm{M}$ inositol was the highest among the groups.

\section{Experiment 3: Optimal RD concentrations in IVC medium}

The results of experiment 3 are presented in Table 4 . In the oocytes with heterogeneous ooplasm, the rates of development to the blastocyst stage were not different among the groups. While not significant, the rate of development to the blatocyst stage with $20 \%$ RD was highest among the groups. On the other hand, in the 
Table 5. Effects of supplementation of N-acetylglucosamine (GlcNAc) in 20\% RD-mKSOM/aa on development to the blastocyst stage of bovine IVM-IVF oocytes

\begin{tabular}{ccccccc}
\hline \multirow{2}{*}{$\begin{array}{c}\text { Type of } \\
\text { oocytes }\end{array}$} & $\begin{array}{c}\text { Concentration } \\
\text { of }\end{array}$ & \multirow{2}{*}{$\begin{array}{c}\text { No. of } \\
\text { oocytes } \\
\text { GlcNAc }(\mathrm{mM})\end{array}$} & \multicolumn{3}{c}{ No. (\%) of oocytes developed to } \\
\cline { 4 - 7 } & examined & $\geq 2$ cells & $\geq 8$ cells & Morula & Blastocyst \\
\hline Hetero & 0 & 78 & $68(87.2)$ & $59(75.6)$ & $53(67.9)$ & $37(47.4)^{\mathrm{a}}$ \\
& 0.6 & 61 & $55(90.2)$ & $50(82.0)$ & $45(73.8)$ & $35(57.4)^{\mathrm{ab}}$ \\
& 1.0 & 73 & $68(93.2)$ & $65(89.0)$ & $58(79.5)$ & $48(65.8)^{\mathrm{b}}$ \\
\hline Homo & 1.2 & 79 & $70(88.6)$ & $63(79.7)$ & $50(63.8)$ & $37(46.8)^{\mathrm{a}}$ \\
\hline & 0 & 76 & $57(75.0)$ & $42(55.3)$ & $33(43.4)$ & $22(28.9)$ \\
& 1.0 & 56 & $41(73.2)$ & $29(51.8)$ & $24(42.9)$ & $18(32.1)$ \\
\hline
\end{tabular}

${ }^{\mathrm{a}, \mathrm{b}}$ Values in the same column with different superscripts are significantly different for each type of oocyte $(\mathrm{P}<0.05)$.

Table 6. Ability to develop into live calves of blastocysts produced with $\mathrm{mKSOM} /$ aa supplemented with $10 \%$ or $20 \% \mathrm{RD}$

\begin{tabular}{|c|c|c|c|c|c|}
\hline $\begin{array}{l}\text { Group of } \\
\text { embryos }\end{array}$ & $\begin{array}{l}\text { Experiment } \\
\text { no. }\end{array}$ & $\begin{array}{l}\text { Quality of } \\
\text { blastocyst }\end{array}$ & $\begin{array}{l}\text { Estrous cycle of } \\
\text { recipient (Day) }\end{array}$ & Pregnancy & Birth of live calves \\
\hline \multirow[t]{7}{*}{ Fresh $^{b}$} & 1 & Excellent & 8 & - & (Returned to estrus on Day 81) \\
\hline & 2 & Excellent & 8 & + & + Live calf ( $₫ 40 \mathrm{~kg}$, Day 310$)$ \\
\hline & 3 & Excellent & 9 & + & + Live calf ( $(30 \mathrm{~kg}$, Day 287) \\
\hline & 4 & Excellent & 8 & - & (Returned to estrus on Day 25) \\
\hline & 5 & Excellent & 8 & + & + Live calf ( $338 \mathrm{~kg}$, Day 285) \\
\hline & 6 & Excellent & 8 & + & + Live calf ( $(43 \mathrm{~kg}$, Day 295) \\
\hline & 7 & Excellent & 8 & - & (Returned to estrus on Day 61) \\
\hline Frozen-thawed & 1 & Excellent & 8 & + & + Live calf ( $935 \mathrm{~kg}$, Day 295) \\
\hline \multirow[t]{2}{*}{$\mathrm{A}^{\mathrm{c}}$} & 2 & Excellent & 8 & - & (Returned to estrus on Day 49) \\
\hline & 3 & Excellent & 6 & + & + Live calf ( $(+27 \mathrm{~kg}$, Day 303$)$ \\
\hline \multirow[t]{6}{*}{$\mathrm{B}^{\mathrm{d}}$} & 1 & Excellent & 8 & + & - Stillbirth (q, Day 286) \\
\hline & 2 & Excellent & 8 & + & + Live calf ( 326 kg, Day 289) \\
\hline & 3 & Excellent & 8 & + & + Live calf ( ${ }^{\wedge} 28 \mathrm{~kg}$, Day 307) \\
\hline & 4 & Excellent & 8 & + & + Live calf ( ${ }^{7} 40 \mathrm{~kg}$, Day 288$)$ \\
\hline & 5 & Excellent & 8 & - & (Returned to estrus on Day 49) \\
\hline & 6 & Excellent & 8 & - & - \\
\hline
\end{tabular}

${ }^{\text {a }}$ Day of estrus=Day $0 .{ }^{\mathrm{b}}$ The blastocysts were produced with $10 \% \mathrm{RD}-\mathrm{mKSOM} / \mathrm{aa}$ containing $1 \mathrm{mg} / \mathrm{ml} \mathrm{PVP,} 0.5 \mathrm{mM}$ citrate and $70.2 \mu \mathrm{M}$ myo-inositol (experiment 1). ${ }^{\mathrm{c}}$ The blastocysts were produced with $20 \% \mathrm{RD}-\mathrm{mKSOM} /$ aa containing $1 \mathrm{mg} / \mathrm{ml} \mathrm{PVP,} 0.5 \mathrm{mM}$ citrate and $70.2 \mu \mathrm{M}$ myo-inositol (experiment 2). ${ }^{\mathrm{d}}$ The blastocysts were produced with $20 \% \mathrm{RD}-\mathrm{mKSOM} / \mathrm{aa}$ containing $1 \mathrm{mg} / \mathrm{ml}$ PVP, $0.5 \mathrm{mM}$ citrate, $70.2 \mu \mathrm{M}$ myo-inositol and $1 \mathrm{mM}$ GlcNAc (experiment 4).

oocytes with homogeneous ooplasm, the rates of development to the morula and blastocyst stages with $30 \%$ RD were significantly lower than those with $20 \%$ RD.

\section{Experiment 4: Effects of supplementation of $\mathrm{N}$-acetylglucos- amine (GlcNAc)}

The results of experiment 4 are presented in Table 5. In the oocytes with heterogeneous ooplasm, there were no differences in the rates of cleavage and development to the 8 -cell or more advanced stages and morula stage among the groups with different concentrations of GlcNAc. However, the rate of development to the blastocyst stage with $1 \mathrm{mM}$ GlcNAc was significantly higher than that without GlcNAc, but the rate of development with $1.2 \mathrm{mM} \mathrm{GlcNAc}$ was not different from that without GlcNAc. On the other hand, in the oocytes with homogeneous ooplasm, there were no differences in the developmental competences at GlcNAc concentrations be- tween $0 \mathrm{mM}$ and $1 \mathrm{mM}$.

\section{Experiment 5: Cryopreservation ability of blastocysts produced} with $10 \%$ RD-mKSOM/aa

After freezing and thawing, the survival rate and rate of development to hatching blastocysts of blastocysts produced in $10 \%$ RD-mKSOM/aa containing $1 \mathrm{mg} / \mathrm{ml}$ PVP, $0.5 \mathrm{mM}$ citrate and 70.2 $\mu \mathrm{M}$ inositol were $85.0 \%(34 / 40)$ and $80.0 \%$ (32/40), respectively.

Experiment 6: Ability to develop into live calves of blatocysts produced with $\mathrm{mKSOM}$ /aa supplemented with $10 \%$ or $20 \%$ RD

The results of experiment 6 are presented in Table 6 . Seven fresh blastocysts produced in 10\% RD-mKSOM/aa containing $1 \mathrm{mg} / \mathrm{ml}$ PVP, $0.5 \mathrm{mM}$ citrate and $70.2 \mu \mathrm{M}$ inositol were transferred to 7 recipients. Four of the seven recipients became pregnant and delivered 4 normal calves. Nine frozen-thawed blastocysts produced 
in $20 \% \mathrm{RD}-\mathrm{mKSOM} /$ aa containing $1 \mathrm{mg} / \mathrm{ml} \mathrm{PVP}, 0.5 \mathrm{mM}$ citrate, $70.2 \mu \mathrm{M}$ inositol and 0 or $1 \mathrm{mM}$ GlcNAc (3 blastocysts with $0 \mathrm{mM}$ GlcNAc and 6 blastocysts with $1 \mathrm{mM}$ GlcNAc) were transferred to 9 recipients. Six of the 9 recipients became pregnant. Of these, 5 delivered live calves; there was 1 stillbirth.

\section{Discussion}

The basic embryo culture medium used in this study was mKSOMaa. In mice, the addition of amino acids to BSA-free KSOM (KSOM/AA) was found to restore the rates of blastocyst formation and hatching $[15,16]$. The $\mathrm{mKSOM} / \mathrm{aa}$ in the present study was a modified form of KSOM/AA medium, and the modified ingredients were $0.3 \mathrm{mM}$ sodium pyruvate [9], $3.0 \mathrm{mM}$ sodium lactate [9], $1.0 \mathrm{mM}$ glucose (in our preliminary experiment), BME amino acids [9] (final concentrations of L-leucine, L-methionine and Ltryptophan being modified to $0.4,0.1$ and $0.05 \mathrm{mM}$, respectively), MEM nonessential amino acids $[9,26]$ (concentration of glycine adjusted to $3 \mathrm{mM}$ [27]) and ITS $(5 \mu \mathrm{g} / \mathrm{ml}$ insulin [28], $5 \mu \mathrm{g} / \mathrm{ml}$ transferrin, $5 \mathrm{ng} / \mathrm{ml}$ sodium selenite). We have reported that $\mathrm{mK}$ $\mathrm{SOM} /$ aa containing BSA without glucose was an embryo culture medium supporting development to the blastocyst stage [17]. However, in our preliminary experiment, $\mathrm{mKSOM}$ /aa with PVP, which is a chemically defined medium, was found to markedly depress the rate of blastocyst formation (data not shown). This result suggests that $\mathrm{mKSOM} / \mathrm{aa}$ is still not sufficient as a chemically defined medium.

On the other hand, protein-free Medium RD (RPMI1640 and Dulbecco's MEM, 1:1 v/v) was shown to be superior to TCM199 for culture of rabbit embryos [18]. We have also reported that modified TCM199 (glucose-free) containing BSA was an embryo culture medium supporting development to the blastocyst stage [17]. Therefore, we hypothesized that Medium RD could be superior to TCM199 for culture of bovine embryos. However, the glucose concentration in Medium RD (8.3 mM) is too high for bovine embryos. Accordingly, we considered using RD as a supplement to $\mathrm{mKSOM} / \mathrm{aa}$ (10\%RD-mKSOM/aa, RD and mKSOM/aa, 1:9 v/v). The results of experiment 1 demonstrated that addition of Mediuum RD to the $\mathrm{m}-\mathrm{KSOM}$ /aa medium resulted in good embryonic development in vitro for a semidefined IVC medium. However, replacement of BSA in this medium with PVP and citrate resulted in decreases in the rates of both blastocyst formation and hatching (Table 2). Although citrate is purified from a commercial BSA as an embryotrophic factor [29], this result shows that BSA cannot be replaced with only citrate and PVP.

As shown in Table 3, the presence of $70.2 \mu \mathrm{M}$ myo-inositol in $10 \% \mathrm{RD}-\mathrm{mKSOM} / \mathrm{aa}$ with citrate and PVP improved the hatching rate of blastocysts, but more than $70.2 \mu \mathrm{M}$ inositol did not improve the hatching rate of blastocysts. Carney and Foote also suggested that a high concentration $(117 \mu \mathrm{M})$ of inositol in RD medium promotes the development of rabbit embryos [18]. Inositol is essential for rabbit blastocyst expansion [30,31] and stimulates hatching of hamster blastocysts [32]. Furthermore, in bovine embryos, inositol is incorporated into phosphoinositides and inositol phosphates, inducing a very large change in the pattern of second messenger formation at the critical stage of blastocyst formation [33]. Holm et al.
[4] reported that the addition of a high myo-inositol concentration $(2.77 \mathrm{mM})$ to SOF medium containing citrate and PVA enhanced bovine embryo development. In the case of a simple culture medium such as SOF, the addition of a high myo-inositol concentration may be required to enhance embryo development in vitro.

As shown in Table 4, the optimal RD concentration in RD-mKSOM/aa with citrate, PVP and inositol was $20 \%$. In addition, RD at a concentration of $30 \%$ caused a reduction in the rate of development to the blastocyst stage. In experiment 3 , on the other hand, the RD concentration in the IVC medium was different among the groups, and the concentrations of inorganic salts, sodium pyruvate, sodium lactate, glucose, $\mathrm{NaHCO}_{3}$, L-glutamine, glycine, myo-inositol, HEPES, citrate, EDTA, ITS and dibekacin sulfate in the IVC medium were the same. The concentrations of vitamins in RD-mKSOM/aa changed in a manner dependent on the RD concentration, and key substances in RD might be vitamins, except myo-inositol. In cattle, culture of bovine embryos with vitamin $\mathrm{E}$ resulted in development of more embryos to early and expanded blastocysts [34]. In hamsters, pantothenate significantly stimulated blastocyst development compared with the effects of the vitaminfree control and other single vitamins except thiamine [35]. In experiment 3 , the concentration of vitamins in $20 \% \mathrm{RD}-\mathrm{mKSOM} / \mathrm{aa}$ may have been suitable for early embryonic development.

As shown in Table 5, GlcNAc at the concentration of $1 \mathrm{mM}$ in $20 \%$ RD-mKSOM/aa containing citrate, PVP and myo-inositol improved the rate of development to the blastocyst stage. GlcNAc exists widely as a component of glycoprotein and glycosaminoglycan in both animals and plants cells. Nancarrow and Hill [19] reported that an oviduct-specific glycoprotein was secreted mainly from day -1 to day 3 of the ovarian cycle and that this ovine estrus-associated glycoprotein enhanced the proportion of sheep oocytes cleaved in vitro. They also suggested that this glycoprotein may have a facilitatory role and in its pure form be a useful component of embryo production media in vitro. The results of this study demonstrate that GlcNAc is beneficial for in vitro embryonic development when added as a supplement to a chemically defined medium for bovine embryos.

Recently, an advanced chemically defined medium for IVC of porcine zygotes named PZM-5 has been developed [36, 37]. Interestingly, PZM-5 is a comparatively simple culture medium. In contrast, the chemically defined medium of $20 \% \mathrm{RD}-\mathrm{mKSOM} / \mathrm{aa}$ used in the present study is a comparatively complicated culture medium. In our preliminary experiment, mKSOM/aa with PVP, which is a comparatively simple culture medium, reduced the rate of development to the blastocyst stage of bovine embryos (data not shown). These results show that the involvement of many substances that exist in an IVC medium is necessary for the development of bovine embryos.

In this study, before IVM, COCs were divided into two groups by the appearance of their ooplasm, homogeneous and heterogeneous. The reason for this was that the appearance of the ooplasm reflects the in vitro developmental competence of the oocytes. We have reported that developmental competence to the blastocyst stage was significantly greater in oocytes with heterogeneous ooplasm than in oocytes with homogeneous ooplasm [17]. Nagano et al. [38] reported that a heterogeneous ooplasm indicated an ac- 
Table 7. Composition of a $20 \% \mathrm{RD}^{*}$-mKSOM/aa chemically defined medium

\begin{tabular}{|c|c|c|c|c|c|}
\hline Component & $\mathrm{mM}$ & Component & $\mathrm{mM}$ & Component & $\mathrm{mM}$ \\
\hline Inorganic salts & & Amino acids & & Vitamines & \\
\hline $\mathrm{NaCl}$ & 98.60 & L-Alanine & 0.08 & Biotin & 0.00008 \\
\hline $\mathrm{KCl}$ & 2.50 & L-Arginine & 0.19 & D-Ca Pantothenate & 0.00006 \\
\hline $\mathrm{CaCl}_{2} \cdot 2 \mathrm{H}_{2} \mathrm{O}$ & 1.71 & L-Arginine $\bullet \mathrm{HCl}$ & 0.04 & D-Pantothenic acid (hemi Ca) & 0.0016 \\
\hline $\mathrm{Ca}\left(\mathrm{NO}_{3}\right)_{2} \bullet 4 \mathrm{H}_{2} \mathrm{O}$ & 0.04 & L-Asparagine & 0.12 & Choline chloride & 0.0050 \\
\hline $\mathrm{MgSO}_{4}$ & 0.20 & L-Aspartic acid & 0.10 & Folic acid & 0.0012 \\
\hline $\mathrm{NaHCO}_{3}$ & 25.00 & L-Cystine $\cdot 2 \mathrm{HCl}$ & 0.12 & Myo-Inositol & 0.0702 \\
\hline $\mathrm{Na}_{2} \mathrm{HPO}_{4}$ & 0.56 & L-Glutamic acid & 0.09 & Niacinamide & 0.0040 \\
\hline $\mathrm{NaH}_{2} \mathrm{PO}_{4}$ & 0.09 & L-Glutamine & 0.68 & Para-aminobenzonic acid & 0.0008 \\
\hline $\mathrm{Fe}\left(\mathrm{NO}_{3}\right)_{3} \cdot 9 \mathrm{H}_{2} \mathrm{O}$ & 0.000024 & Glycine & 3.00 & Pyridoxine $\mathrm{HCl}$ & 0.0024 \\
\hline $\mathrm{KH}_{2} \mathrm{PO}_{4}$ & 0.35 & L-Histidine & 0.05 & Riboflavin & 0.00016 \\
\hline Other components & & L-Histidine $\bullet \mathrm{HCl} \cdot 2 \mathrm{H}_{2} \mathrm{O}$ & 0.02 & Thiamine $\mathrm{HCl}$ & 0.0014 \\
\hline D-glucose & 1.00 & L-Hydroxyproline & 0.02 & Vitamine $\mathrm{B}_{12}$ & 0.0004 \\
\hline Sodium pyruvate & 0.30 & L-Isoleucine & 0.28 & & \\
\hline Sodium lactate & 3.00 & L-Leucine & 0.44 & & \\
\hline EDTA (4Na) & 0.01 & L-Lysine $\bullet \mathrm{HCl}$ & 0.26 & & \\
\hline Glutathione & 0.00033 & L-Methionine & 0.11 & & \\
\hline Sodium citrate & 0.50 & L-Phenylalanine & 0.13 & & \\
\hline $\mathrm{N}$-acetylglucosamine & 1.00 & L-Proline & 0.10 & & \\
\hline Insulin & $5 \mu \mathrm{g} / \mathrm{ml}$ & L-Serine & 0.15 & & \\
\hline Transferrin & $5 \mu \mathrm{g} / \mathrm{ml}$ & L-Threonine & 0.26 & & \\
\hline Sodium selenite & $5 \mathrm{ng} / \mathrm{ml}$ & L-Tryptophan & 0.05 & & \\
\hline PVP & $1 \mathrm{mg} / \mathrm{ml}$ & L-Tyrosine $\cdot 2 \mathrm{Na} \cdot 2 \mathrm{H}_{2} \mathrm{O}$ & 0.13 & & \\
\hline HEPES (pH 7.4) & 10.00 & L-Valine & 0.26 & & \\
\hline Dibekacin sulfate & $65 \mu \mathrm{g} / \mathrm{ml}$ & & & & \\
\hline Phenol red & 0.026 & & & & \\
\hline
\end{tabular}

* RD: Glucose-free RPMI1640 and Dulbeccós MEM (low glucose), 1:1 (v/v).

cumulation of lipids and good developmental potential, whereas a homogeneous ooplasm indicated aging and low developmental potential. In the present study, the effects of RD, inositol and GlcNAc were marked in oocytes with heterogeneous ooplasm. Although the reason why there is a difference in reactivity to $\mathrm{RD}$, inositol and GlcNAc between heterogeneous ooplasm and homogeneous ooplasm is unknown, a possible reason is that oocytes with heterogeneous ooplasm are developmentally more competent and that this developmental competence is induced by supplementation of $\mathrm{RD}$, inositol and GlcNAc.

In experiment 5 , blastocysts produced with the $10 \% \mathrm{RD}-\mathrm{mK}$ SOM/aa chemically defined medium showed high ability of cryopreservation. In cattle, in vivo cultured embryos are superior in terms of cryosurvival to their in vitro cultured counterparts [39, 40]. At least, the results of experiment 5 indicate that advancement of the IVC system contributes to improvement of blastocyst quality measured in terms of survival after cryopreservation.

The results of experiment 6 showed that blatocysts produced in $\mathrm{mKSOM}$ /aa supplemented with $10 \%$ or $20 \%$ RD had higher ability to develop into live calves (Table 6). Large offspring syndrome has been observed in bovine and ovine offspring following transfer of IVP or cloned embryos [6-8, 41, 42]. Lazzari et al. [43] reported that birth weights of calves derived from bovine embryos produced with SOF medium supplemented with serum or BSA were significantly larger than those of calves derived from sheep oviduct cul- ture, superovulation or artificial insemination. In the present study, the birth weights of calves were normal, indicating that it is important to establish an IVC system with a chemically defined medium.

In conclusion, $20 \% \mathrm{RD}-\mathrm{mKSOM} / \mathrm{aa}$ with $70.2 \mu \mathrm{M}$ myo-inositol, $1 \mathrm{mg} / \mathrm{ml}$ PVP, $0.5 \mathrm{mM}$ sodium citrate and $1 \mathrm{mM}$ GlcNAc (Table 7) is an advanced chemically defined medium for bovine embryos. The results of this study should contribute to the improvement of an IVC system for bovine embryos.

\section{Acknowledgments}

This work was supported by grants from the Ministry of Agriculture, Forestry and Fisheries of Japan and the Kitasato University School of Veterinary Medicine.

\section{References}

1. Marquant-Leguienne B, Humblot P. Practical measures to improve in vitro blastocyst production in the bovine. Theriogenology 1998; 49: 3-11. [Medline] [CrossRef]

2. Lim JM, Okitsu O, Okuda K, Niwa K. Effects of fetal calf serum in culture medium on development of bovine oocytes matured and fertilized in vitro. Theriogenology 1994; 41: 1091-1098. [Medline] [CrossRef]

3. Van Langendonckt A, Donnay I, Schuurbiers N, Auquier P, Carolan C, Massip A, Dessy F. Effects of supplementation with fetal calf serum on development of bovine embryos in synthetic oviduct fluid medium. J Reprod Fertil 1997; 109: 87-93. [Medline] [CrossRef]

4. Holm P, Booth PJ, Schmidt MH, Greve T, Callesen H. High bovine blastocyst de- 
velopment in a static in vitro production system using SOFaa medium supplemented with sodium citrate and myo-inositol with or without serum-proteins. Theriogenology 1999; 52: 683-700. [Medline] [CrossRef]

5. Pinyopummintr T, Bavister BD. Development of bovine embryos in a cell-free culture medium: Effects of type of serum, timing of its inclusion and heat inactivation. Theriogenology 1994; 41: 1241-1249. [Medline] [CrossRef]

6. Holm P, Walker SK, Seamark RF. Embryo viability, duration of gestation and birth weight in sheep after transfer of in vitro matured and in vitro fertilized zygotes cultured in vitro or in vivo. J Reprod Fertil 1996; 107: 175-181. [Medline]

7. Thompson JG, Gardner DK, Pugh PA, McMillan WH, Tervit HR. Lamb birth weight is affected by the culture system utilized during in vitro pre-elongation development of ovine embryos. Biol Reprod 1995; 53: 1385-1391. [Medline] [CrossRef]

8. van Wagtendonk-de Leeuw AM, Aerts BJG, Den Dass JHG. Abnormal offspring following in vitro production of bovine preimplantation embryos: a field study. Theriogenology 1998; 49: 883-894. [Medline] [CrossRef]

9. Takahashi Y, First NL. In vitro development of bovine embryos: influence of glucose, lactate, pyruvate, amino acids and vitamins. Theriogenology 1992; 37: 963-978. [Medline] [CrossRef]

10. Carolan C, Lonergan P, Van Longendonkt A, Mermillod P. Factors affecting bovine embryo development in synthetic oviduct fluid following oocyte maturation and fertilization in vitro. Theriogenology 1995; 43: 1115-1128. [Medline] [CrossRef]

11. Keskintepe L, Brackett BG. In vitro developmental competence of in vitro-matured bovine oocytes fertilized and cultured in completely defined media. Biol Reprod 1996 55: 333-339. [Medline] [CrossRef]

12. Rosenkrans CF, Zeng GQ, McNamara GT, Schoff PK, First NL. Development of bovine embryos in vitro as affected by energy substrates. Biol Reprod 1993; 49: 459-462. [Medline] [CrossRef]

13. Liu Z, Foote RH. Development of bovine embryos in KSOM with added superoxide dismutase and taurine and with five and twenty percent $\mathrm{O}_{2}$. Biol Reprod 1995; 53: 786-790. [Medline] [CrossRef]

14. Lawitts JA, Biggers JD. Culture of preimplantation embryos. Methods Enzymol 1993; 225: 153-164. [Medline] [CrossRef]

15. Ho Y, Wiggresworth K, Eppig JJ, Schultz RM. Preimplantation development of mouse embryos in KSOM: augmentation by amino acids and analysis of gene expression. Mol Reprod Dev 1995; 41: 232-238. [Medline] [CrossRef]

16. Biggers JD, Summers MC, McGinnis LK. Polyvinyl alcohol and amino acids as substitutes for bovine serum albumin in mouse preimplantation embryo culture media. Hum Reprod Update 1997; 3: 125-135. [Medline] [CrossRef]

17. Momozawa K, Fukuda Y. Effects of fractions of bovine follicular fluid and fetal bovine serum as supplements to maturation medium on in vitro development of in vitro fertilized bovine embryo. J Mamm Ova Res 2011; 28: 68-74. [CrossRef]

18. Carney EW, Foote RH. Improved development of rabbit one-cell embryos to the hatching blastocyst stage by culture in a defined, protein-free culture medium. J Reprod Fertil 1991; 91: 113-123. [Medline] [CrossRef]

19. Nancarrow CD, Hill JH. Oviduct proteins in fertilization and early embryo development. J Reprod Fertil Suppl 1995; 49: 3-13. [Medline]

20. Momozawa K, Fukuda Y. In vitro maturation and in vitro fertilization of bovine with heterogeneous ooplasm. Anim Sci Technol 1995; 66: 605-609. (In Japanese)

21. Brackett BG, Oliphant G. Capacitation of rabbit spermatozoa in vitro. Biol Reprod 1975; 12: 260-274. [Medline] [CrossRef]

22. Momozawa K, Fukuda Y. Caffeine in fertilization medium is not essential for bovine IVF by fully capacitated spermatozoa. J Reprod Dev 2003; 49: 507-512. [Medline] [CrossRef]

23. Taguma K, Nakamura C, Ozaki A, Suzuki C, Hachisu A, Kobayashi K, Mochida K, Ogura A, Kaneda H, Wakana S. A practical novel method for ensuring stable capacitation of spermatozoa from cryopreserved C57BL/6J sperm suspension. Exp Anim 2009; 58: 395-401. [Medline] [CrossRef]
24. Whittingham DG. Survival of mouse embryos after freezing and thawing. Nature (Lond) 1971; 233: 125-126. [Medline] [CrossRef]

25. Schneider I, Blumenthal A. Drosophila cell and tissue culture. In: Ashbumer M, Wright TRF (eds.), Biology and Genetics of Drosophila vol. 2A. New York: Academic Press; 1978: 266-315.

26. Liu Z, Foote RH. Effects of amino acids on the development of in-vitro matured/in vitro fertilization bovine embryos in a simple protein-free medium. Hum Reprod 1995; 10: 2985-2991. [Medline]

27. Takahashi Y, Kanagawa H. Effects of glutamine, glycine and taurine on the development of in vitro fertilized bovine zygotes in a chemically defined medium. J Vet Med Sci 1998; 60: 433-437. [Medline] [CrossRef]

28. Matsui M, Takahashi Y, Hishinuma M, Kanagawa H. Stimulatory effects of insulin on the development of bovine embryos fertilized in vitro. I Vet Med Sci 1995; 57: 331-336. [Medline] [CrossRef]

29. Gray CW, Morgan PM, Kane MT. Purification of an embryotrophic factor from commercial bovine serum albumin and its identification as citrate. J Reprod Fertil 1992; 94 471-480. [Medline] [CrossRef]

30. Kane MT. Effects of the putative phospholipid precursors, inositol, choline, serine and ethanolamine, on formation and expansion of rabbit blastocysts in vitro. J Reprod Fertil 1989; 87: 275-279. [Medline] [CrossRef]

31. Fahy MM, Kane MT. Inositol stimulates DNA and protein synthesis, and expansion by rabbit blastocysts in vitro. Hum Reprod 1992; 7: 550-552. [Medline]

32. Kane MT, Bavister BD. Vitamin requirements for development of eight-cell embryos to hatching blastocysts in vitro. Biol Reprod 1988; 39: 1137-1143. [Medline] [CrossRef]

33. Hynes AC, Sreenan JM, Kane MT. Uptake and incorporation of myo-inositol by bovine preimplantation embryos from two-cell to early blastocyst stages. Mol Reprod Dev 2000; 55: 265-269. [Medline] [CrossRef]

34. Olson SE, Seidel GE Jr. Culture of in vitro-produced bovine embryos with vitamin E improves development in vitro and after transfer to recipients. Biol Reprod 2000; 62: 248-252. [Medline] [CrossRef]

35. McKiernan SH, Bavister BD. Culture of one-cell hamster embryos with water-soluble vitamins: pantothenate stimulates blastocyst production. Hum Reprod 2000; 15 157-164. [Medline] [CrossRef]

36. Suzuki C, Yoshioka K. Effects of amino acid supplements and replacement of polyvinyl alcohol with bovine serum albumin in porcine zygote medium. Reprod Fertil Dev 2006; 18: 789-795. [Medline] [CrossRef]

37. Yoshioka K, Suzuki C, Onishi A. Defined system for in vitro production of porcine embryos using a single basic medium. J Reprod Dev 2008; 55: 208-213. [Medline] [CrossRef]

38. Nagano M, Katagiri S, Takahashi Y. Relationship between bovine oocyte morphology and in vitro developmental potential. Zygote 2006; 14: 53-61. [Medline] [CrossRef]

39. Enright BP, Lonergan P, Dinnyes A, Fair T, Ward FA, Yang X, Boland MP. Culture of in vitro produced bovine zygotes in vitro vs in vitro: implications for early embryo development and quality. Theriogenology 2000; 54: 659-673. [Medline] [CrossRef]

40. Rizos D, Ward FA, Duffy P, Boland MP, Lonergan P. Consequences of bovine oocyte maturation, fertilization or early embryo development in vitro versus in vivo: implications for blastocyst yield and blastocyst quality. Mol Reprod Dev 2002; 61: 234-248. [Medline] [CrossRef]

41. Hasler JF, Henderson WB, Hurtgen PJ, Jin ZQ, McCauley AD, Mower SA, Neely B Shuey LS, Stokes JE, Trimmer SA. Production, freezing and transfer of bovine IVF embryos and subsequent calving results. Theriogenology 1995; 43: 141-152. [CrossRef]

42. Kruip ThAM, Den Daas JHG. In vitro produced and cloned embryos: effects on pregnancy, parturition and offspring. Theriogenology 1997; 47: 43-52. [CrossRef]

43. Lazzari G, Wrenzycki C, Herrmann D, Duchi R, Kruip T, Niemann H, Galli C. Cellular and molecular deviations in bovine in vitro-produced embryos are related to the large offspring syndrome. Biol Reprod 2002; 67: 767-775. [Medline] [CrossRef] 